\title{
PERMANENT GENETIC RESOURCES Ten polymorphic STR loci in the cosmopolitan reef coral,
Pocillopora damicornis
}

\author{
CRAIG J. STARGER,*SEAN S. R. YEOH,+CHANG-FENG DAI, †ANDREW C. BAKER ${ }^{*}$ \\ and ROB DESALLE§ \\ *Department of Ecology, Evolution, and Environmental Biology, Columbia University, MC-5557, 1200 Amsterdam Avenue, New York, \\ NY 10027, USA, +Division of Marine Biology and Fisheries, Institute of Oceanography, National Taiwan University, no. 1, Sec. 4, \\ Roosevelt Road, Taipei 10617, Taiwan, $\ddagger$ Division of Marine Biology and Fisheries, Rosenstiel School of Marine and Atmospheric Science, \\ University of Miami, 4600 Rickenbacker Causeway, Miami, FL 33149, USA, §Sackler Institute for Comparative Genomics, American \\ Museum of Natural History, New York, NY 10024, USA
}

\begin{abstract}
We report the development of 10 polymorphic molecular markers containing short tandem repeats in the cosmopolitan reef-building coral, Pocillopora damicornis, an important model species for coral health, physiology, ecology, and genetics. The availability of polymorphic DNA markers in P. damicornis can act as impetus for investigations into inheritance and population genetics, as well as novel investigations into host-symbiont ecology and evolution. Coral bleaching and gene flow studies performed with these markers can have direct conservation implications.
\end{abstract}

Keywords: connectivity, coral reef, gene flow, microsatellite, population genetics, Scleractinia

Received 2 July 2007; revision accepted 29 August 2007

The application of DNA markers containing short tandem repeats (STRs), colloquially referred to as 'microsatellites', is the most popular method currently used in molecular population genetics (DeSalle \& Amato 2004). STR loci have been discovered in several Indo-Pacific coral species (Maier et al. 2001; Miller \& Howard 2004; Underwood et al. 2005). Here we characterize 10 new STR loci in the cosmopolitan coral, Pocillopora damicornis. Common throughout the Indo-Pacific, $P$. damicornis has the widest distribution of any known scleractinian coral genus (the entire IndoPacific from the Red Sea to Central America). As such, it has become a model species for investigations into coral health, physiology, ecology, genetics and climate change response.

High molecular weight DNA was isolated from one individual of P. damicornis from Indonesia and one from Taiwan using the QIAGEN DNeasy Tissue Kit and digested with RsaI. STR enrichment followed Glenn \& Schable (2005) except for our choice of biotinylated oligonucleotide probes: $(\mathrm{AC})_{10}(\mathrm{AG})_{10}(\mathrm{ACC})_{6}(\mathrm{AGG})_{6}(\mathrm{AGC})_{6}(\mathrm{ACG})_{6}(\mathrm{CCG})_{5}(\mathrm{AAG})_{8}$ $(\mathrm{AAT})_{10}(\mathrm{ATC})_{8}(\mathrm{ACT})_{8}$ and $(\mathrm{AAC})_{8}($ Rob J. Toonen, Hawai'i Institute of Marine Biology, personal communication).

Correspondence: Craig J. Starger, E-mail: cjs52@columbia.edu
Cloning was performed with Invitrogen's TOPO TA cloning kit, One Shot TOP10 cells and imMedia agar plates following manufacturer's protocols. Positive clones were directly sequenced using the BigDye Terminator method (Applied Biosystems) on an ABI 3730xl. Sequences were edited in SEquencher 4.6 (Gene Codes). The Simple Sequence Repeat Identification Tool (Temnykh et al. 2001) was used to search for STRs. Primers were designed for 20 putative loci using PRIMER 3 (Rozen \& Skaletsky 2000) and checked for applicability to multiplex polymerase chain reaction (PCR) using AUTODIMER with a threshold score of 7 (Vallone \& Butler 2004).

Genomic DNA was extracted from 21 individuals from Raja Ampat, West Papua, Indonesia ( $\left.0^{\circ} 33.384^{\prime} \mathrm{S}, 130^{\circ} 40.681^{\prime} \mathrm{E}\right)$ using a modified Chelex protocol (Walsh et al. 1991). PCR amplifications for the markers Pd2-001 to Pd2-006 (10 $\mu \mathrm{L}$ total volume) contained $0.5 \mu \mathrm{L}$ DNA template (c. $10 \mathrm{ng}), 0.25 \mathrm{U}$ Taq polymerase (Promega), $1 \mu \mathrm{L}$ of $10 \times$ PCR buffer, $0.8 \mathrm{~mm}$ dNTPs, $2 \mathrm{~mm} \mathrm{MgCl} 2$ and $0.1 \mu \mathrm{M}$ of each primer. The cycling protocol was: $1 \times 94{ }^{\circ} \mathrm{C}(3 \mathrm{~min}), 35 \times\left[1 \mathrm{~min}\right.$ at $94{ }^{\circ} \mathrm{C}, 1 \mathrm{~min}$ $55^{\circ} \mathrm{C}$ and $1 \mathrm{~min}$ at $74{ }^{\circ} \mathrm{C}$ ] and $1 \times 74^{\circ} \mathrm{C}(7 \mathrm{~min})$. For markers $\mathrm{Pd} 2-007$ to Pd3-010, DNA template volumes were reduced to $0.1 \mu \mathrm{L}$ for each $10 \mu \mathrm{L}$-reaction, and the primer concentrations were increased to $0.3 \mu \mathrm{M}$ each. The cycling protocol was 
Table 1 Pocillopora damicornis loci were named following the format of Underwood et al. (2005): first the prefix Pd for the species name, then 2 or 3 according to repeat motif type (di- or trimer), followed by the number that they appear here. Twenty-one coral colonies were genotyped from Kri Island, Raja Ampat, Indonesia $\left(0^{\circ} 33.384^{\prime} \mathrm{S}, 130^{\circ} 40.681^{\prime} \mathrm{E}\right) . N_{\mathrm{a}}$ refers to number of alleles. $H_{\mathrm{E}}$ and $H_{\mathrm{O}}$ refer to the expected and observed heterozygosities. GenBank Accession numbers are DQ684672-7 and EF120462-5. Departure from Hardy-Weinberg equilibrium is noted with an asterisk

\begin{tabular}{|c|c|c|c|c|c|c|c|c|c|}
\hline Locus & Primer sequences $\left(5^{\prime}-3^{\prime}\right)$ & $\begin{array}{l}T_{\mathrm{a}} \\
(\mathrm{oC})\end{array}$ & STR motif & Dye & $\begin{array}{l}\text { Size range } \\
\text { (bp) }\end{array}$ & $N_{\mathrm{a}}$ & $H_{\mathrm{E}}$ & $H_{\mathrm{O}}$ & $\begin{array}{l}\text { HWE } \\
\text { ( } P \text { value })\end{array}$ \\
\hline Pd2-001 & $\begin{array}{l}\text { CAGACTTGTCGGAATGAAAGC } \\
\text { TTTTGTTTATAAGTCGATACAATGCA }\end{array}$ & 55 & $(\mathrm{CA})_{11}$ & 6FAM & $158-173$ & 5 & 0.650 & 0.600 & 0.27680 \\
\hline Pd3-002 & $\begin{array}{l}\text { ATCCGAATACAAGCGAAACG } \\
\text { CAAAGCTTCTATCAGAAAATGCAA }\end{array}$ & 55 & $(\mathrm{AAC})_{10}$ & NED & $195-243$ & 10 & 0.810 & 0.863 & 0.40686 \\
\hline $\mathrm{Pd} 2-003$ & $\begin{array}{l}\text { CСTCTTCCTGTTTGGGCTCT } \\
\text { TCTGCATTACGTTTGTTTGACA }\end{array}$ & 55 & $(\mathrm{CA})_{16}$ & VIC & 198-202 & 3 & 0.333 & 0.475 & 0.36116 \\
\hline Pd3-004 & $\begin{array}{l}\text { ACCAGACAGAAACACGCACA } \\
\text { GCAATGTGTAACAGAGGTGGAA }\end{array}$ & 55 & $(\mathrm{ATG})_{8}$ & 6FAM & 193-201 & 4 & 0.444 & 0.705 & 0.05446 \\
\hline Pd3-005 & $\begin{array}{l}\text { AGAGTGTGGACAGCGAGGAT } \\
\text { GTTCCTTCGCCTTCGATTTT }\end{array}$ & 55 & $(\mathrm{TGA})_{9}$ & 6FAM & $162-187$ & 3 & 0.450 & 0.376 & 1.00000 \\
\hline Pd2-006 & $\begin{array}{l}\text { ATCTCCATGTGATCGGCATT } \\
\text { GTTCCCCCAGCTGAGAAGTT }\end{array}$ & 55 & $(\mathrm{CA})_{8}$ & VIC & 181-199 & 7 & 0.700 & 0.759 & 0.03282 \\
\hline $\mathrm{Pd} 2-007$ & $\begin{array}{l}\text { AAGAAGGTGTGGTATTTCAGAGGG } \\
\text { GGTGGATAAAGTATTTCTCACTCTTGG }\end{array}$ & 60 & (AC) imperfect & HEX & $307-489$ & 7 & 0.762 & 0.770 & $0.00112^{*}$ \\
\hline Pd3-008 & $\begin{array}{l}\text { AGTTGAGGTTGTTGAAACATG } \\
\text { TCCATGCAGAACCCC }\end{array}$ & 60 & $(\mathrm{CTG})_{7}$ & 6FAM & $153-162$ & 4 & 0.571 & 0.660 & 0.08876 \\
\hline Pd3-009 & $\begin{array}{l}\text { CCAATGCGTCCGTAGCTCTC } \\
\text { ATCACCTAAAAATTTCAGTCCCTTACC }\end{array}$ & 47 & $\begin{array}{l}(\mathrm{CAA}) 7,[88 \mathrm{bp} \\
\text { insert], }(\mathrm{GAG})_{6}\end{array}$ & 6FAM & $339-358$ & 6 & 0.810 & 0.820 & 0.06195 \\
\hline Pd3-010 & $\begin{array}{l}\text { CTGATCAACAAACTGGGAGGC } \\
\text { TCATTAGAAATCATCTTGATTTGATAAGG }\end{array}$ & 47 & $(\mathrm{GTT})_{5},(\mathrm{TGC})_{11}$ & 6FAM & $259-281$ & 7 & 0.762 & 0.761 & 0.24938 \\
\hline
\end{tabular}

modified as: $1 \times 94{ }^{\circ} \mathrm{C}(2 \mathrm{~min}), 30 \times\left[1 \mathrm{~min}\right.$ at $94^{\circ} \mathrm{C}, 20$ s at the annealing temperature, $15 \mathrm{~s}$ at $\left.74^{\circ} \mathrm{C}\right]$ and $1 \times 72^{\circ} \mathrm{C}(1 \mathrm{~min})$.

Size fragment analysis was performed with fluorescentlabelled primers on an ABI 3730xl running GENEMAPPER 3.5 software. Results from all 10 markers are presented in Table 1. Hardy-Weinberg equilibrium was assessed using exact tests based on contingency tables in ARLEQUIN 3.11 (Excoffier et al. 2005). Only locus Pd2-007 showed a significant departure from equilibrium after Bonferroni correction. Linkage disequilibrium, assessed using contingency tables in ARLEQUIN 3.11, was only significant in two out of 90 pairwise comparisons at the $P<0.01$ level (locus Pd2-003 vs. Pd3-004, and locus Pd2-006 vs. Pd3-009) indicating virtually no linkage among loci.

With 10 reliable STR loci available for P. damicornis, investigators may now address questions of inheritance, population genetics, and reproduction with greater power and precision. These markers will also facilitate investigations into symbiosis ecology, specifically the flexibility of the coral-algal symbiosis in response to climate change. Finally, gene flow estimates may be applied to source-sink population dynamics and the design of marine reserve networks.

\section{Acknowledgements}

We thank George Amato, Howard Rosenbaum and Matt Leslie for coordinating the Microsatellite Tutorial at the American Museum of Natural History, and Chien-Hsun Oscar Chen and Shang-Yin Vanson Liu for suggestions during the development. Funding was provided by NSF (Baker, DeSalle), the Sackler Institute for Comparative Genomics, the Wildlife Conservation Society, and National Science Council (Dai), Taiwan. Sample collection and export in Indonesia were facilitated by Paul Barber (Boston University) and the Indonesian Institute of Sciences (LIPI) under research permit \# 2712/SU/KS/2005 and CITES export permit number \# 07218/ IV/SATS-LN/2006.

\section{References}

DeSalle R, Amato G (2004) The expansion of conservation genetics. Nature Reviews Genetics, 5, 702-712.

Excoffier L, Laval G, Schneider S (2005) ARLEQUIN, version 3.0: an integrated software package for population genetics data analysis. Evolutionary Bioinformatics Online, 1, 47-50.

Glenn TC, Schable NA (2005) Isolating microsatellite DNA loci. Methods in Enzymology, 395, 202-222.

Maier E, Tollrain R, Nurnberger B (2001) Development of speciesspecific markers in an organism with endosymbionts: microsatellites in the scleractinian coral Seriatopora hystrix. Molecular Ecology Notes, 1, 157-159.

Miller KJ, Howard CG (2004) Isolation of microsatellites from two species of scleractinian coral. Molecular Ecology Notes, 4, 1113.

Rozen S, Skaletsky H (2000) PRIMER 3 on the WWW for general users and for biologist programmers. In: Bioinformatics Methods and Protocols: Methods in Molecular Biology (eds Krawetz S, Misener S), pp. 365-386. Humana Press, Totowa, New Jersey. 
Temnykh S, DeClerck G, Lukashova A et al. (2001) Computational and experimental analysis of microsatellites in rice (Oryza sativa L.): frequency, length variation, transposon associations, and genetic marker potential. Genome Research, 11, 1441-1452.

Underwood JN, Souter PB, Ballment ER, Lutz AH, van Oppen MJH (2005) Development of ten polymorphic microsatellite markers from herbicide bleached tissues of the brooding pocilloporid coral Seriatopora hystrix. Molecular Ecology Notes, 6, 176-178.

Vallone PM, Butler JM (2004) AUTODIMER: a screening tool for primer-dimer and hairpin structures. BioTechniques, 37, 226-231.

Walsh PS, Metzger DA, Huiguchi R (1991) Chelex 100 as a medium for simple extraction of DNA for PCR-based typing from forensic material. BioTechniques, 10, 506-513. 